\title{
PENGARUH MINYAK DAN GAS TERHADAP KINERJA PERTUMBUHAN EKONOMI REGIONAL: SEBUAH KUTUKAN ATAU ANUGERAH?
}

\author{
Ahmad Fahriza \\ ahmad.fahriza1993@gmail.com \\ Djoni Hartono \\ Departemen Ilmu Ekonomi, Fakultas Ekonomi dan Bisnis, Universitas Indonesia
}

\begin{abstract}
Natural resources, particularly oil and gas, are great benefit to the region that owns it and become one of the region's revenue sources. Nevertheless, Sachs and Warner (1995) found a phenomenon of natural resource curse indicating that the wealth of natural resources could hamper the economic growth. This research tries to see the existence of natural resource curse phenomenon in Indonesia through the performance of regional economic growth; and observes the differences of oil and gas contribution in the economic structure as an indicator of natural resource wealth in the area. Gross Regional Domestic Product Growth (PDRB) per capita without oil and gas is an indicator of the economic growth to see if the oil and gas are inhibiting or accelerating the growth of other sectors in the region's economy. Using data from 33 provinces in Indonesia within the period of 2006-2013, this study found a positive relationship between oil and gas contribution and per capita GDP growth without oil and gas. Based on these findings, natural oil and gas resources have become a boon to the province that owns them.
\end{abstract}

Key words : Indonesia; resource-curse oil and gas; GRDP growth per-capita

\section{ABSTRAK}

Sumber daya alam, khususnya minyak dan gas, merupakan keuntungan bagi daerah yang memilikinya dan menjadi salah satu sumber pendapatan daerah tersebut. Namun demikian, Sachs dan Warner (1995) menemukan adanya fenomena kutukan sumber daya alam yang menunjukkan bahwa kekayaan sumber daya alam dapat menghambat pertumbuhan ekonomi. Penelitian ini mencoba melihat eksistensi fenomena kutukan sumber daya alam di Indonesia melalui kinerja pertumbuhan ekonomi regional. Lebih lanjut dengan melihat perbedaan kontribusi minyak dan gas dalam struktur perekonomian sebagai indikator kekayaan sumber daya alam di daerah tersebut. Pertumbuhan Produk Domestik Regional Bruto (PDRB) per kapita tanpa minyak dan gas menjadi indikator pertumbuhan ekonomi untuk melihat apakah kekayaan minyak dan gas menjadi penghambat atau mempercepat pertumbuhan sektor lainnya dalam perekonomian daerah tersebut. Dengan menggunakan data 33 provinsi di Indonesia dalam rentang waktu 2006-2013, penelitian ini menemukan bahwa terdapat hubungan positif antara kontribusi minyak dan gas dengan pertumbuhan PDRB per kapita tanpa minyak dan gas. Berdasarkan temuan tersebut, sumber daya alam minyak dan gas telah menjadi anugerah bagi provinsi yang memilikinya.

Kata kunci: Indonesia; kutukan sumber daya alam; minyak dan gas; pertumbuhan PDRB per kapita

\section{PENDAHULUAN}

Komoditas minyak dan gas (migas) masih menjadi komoditas energi paling penting di dunia. Kontribusi migas pada tahun 2013 berdasarkan data International Energy Agency (IEA) mencapai 55 persen dari total konsumsi energi akhir dunia. Tercatat bahwa kontribusi minyak bumi dan gas terhadap konsumsi akhir energi di dunia pada tahun 2013 masing-masing sebesar 39,9 persen dan 15,1 persen. Besaran tersebut juga mewakili kontribusi migas sebagai sumber energi yang paling banyak dikonsumsi di dunia. Sebagai sumber utama energi, migas menjadi komoditas yang paling sering diperdagangkan di dunia. 
Pentingnya komoditas migas dalam perekonomian telah membuat negara-negara penghasil minyak dapat menikmati manfaat dari kekayaan migas yang dimilikinya. Selain sebagai sumber energi untuk kegiatan produksi, komoditas migas juga dapat menjadi komoditas ekspor yang mudah dijual. Hal ini tentunya membuat kegiatan produksi migas dapat menjadi salah satu sumber pendapatan negara untuk mendukung pembangunan dan pertumbuhan ekonomi.

Memiliki sumber daya alam yang melimpah merupakan modal bagi negara untuk melakukan pembangunan dan mensejahterakan masyarakat. Sebagai komoditas sumber daya alam (SDA) yang sangat penting, SDA migas tentu menjadi keuntungan bagi negara yang memilikinya. Namun fakta yang terjadi di dunia memperlihatkan adanya indikasi bahwa negara dengan kekayaan alam melimpah justru dapat mengalami pertumbuhan ekonomi yang lebih lambat dibandingkan dengan negara yang secara relatif justru memiliki sedikit kekayaan alam. Fenomena ini dikenal dengan istilah "kutukan sumber daya alam" atau "resource curse".

Menurut Ross (2015), fenomena resource curse atau kutukan sumber daya alam adalah efek negatif dari kekayaan sumber daya alam terhadap keadaan ekonomi, politik dan sosial. Istilah ini pertama kali diangkat oleh Auty (1994) dalam tesisnya yang berjudul "Industrial policy reform in six newly industrializing countries: the resource curse thesis". Kemudian fenomena ini diteliti lebih lanjut oleh Sachs dan Warner (1995). Penelitian tersebut menemukan bahwa kekurangan SDA bukan menjadi penghalang bagi pembangunan ekonomi. Negara-negara dengan kekayaan alam yang lebih sedikit, menunjukkan kinerja pertumbuhan ekonomi yang lebih baik dibandingkan dengan negara yang kaya akan SDA. Beberapa negara dengan SDA yang sedikit tetapi relatif sukses dalam membangun perekonomiannya antara lain adalah Hongkong, Korea, Singapura, dan Taiwan. Di sisi lain, terdapat negara-negara yang memiliki sumber daya alam melimpah justru mengalami perlambatan dalam pertumbuhan ekonomi negaranya.

Proses terjadinya resource curse dapat dijelaskan oleh sejarah yang dialami oleh Belanda sekitar tahun 1970. Saat itu Belanda sedang mengalami peningkatan kekayaan secara drastis setelah penemuan ladang gas di kawasan Laut Utara. Eksplorasi secara terus menerus dilakukan mengingat harga komoditas tersebut sedang cukup tinggi. Kemudian Belanda terus mengembangkan sektor tersebut hingga menjadi komoditas ekspor utama negara tersebut. Proses tersebut secara perlahan menyebabkan apresiasi nilai mata uang Gulden dan nilai riil komoditas ekspor dari sektor-sektor selain gas mengalami apresiasi, menyebabkan barang-barang tersebut relatif mahal di pasar internasional sehingga sektor-sektor selain migas tersebut mengalami penurunan daya saing di pasar internasional. Kejadian ini dikenal dengan istilah "dutch disease" (Ebrahimzadeh, 2012).

Terkait dengan kekayaan sumber daya alam, Indonesia merupakan salah satu negara yang memiliki sumber daya alam relatif besar khususnya minyak dan gas. Bahkan minyak dan gas telah menjadi salah satu sumber utama pendapatan negara. Keberadaan minyak yang relatif besar telah banyak membiayai beberapa pembangunan fisik khususnya pada saat era orde baru di mana Indonesia pernah merasakan periode kejayaan akan migas. Namun, ekstraksi minyak dan gas secara terus menerus membuat perlahan-lahan produksi minyak dan gas Indonesia terus mengalami penurunan. Gambar 1 menunjukkan sumbangan minyak dan gas terhadap Produk Domestik Bruto (PDB) Indonesia mencapai 12 persen pada tahun 2000. Kontribusi tersebut perlahan terus mengalami tren penurunan hingga mencapai 5 persen di tahun 2013. Kontribusi sebesar 5 persen pada PDB Indonesia di tahun 2013 tersebut mewakili nilai PDB riil sebesar Rp.123,1 Triliun dari total PDB sebesar Rp.2.661 
Triliun (PDB riil didasarkan harga konstan dengan tahun dasar 2000).

Berdasarkan persebaran produksi migas di Indonesia, terdapat ketidakmerataan produksi migas antar-provinsi di Indonesia. Gambar 2 menunjukkan rata-rata sumbangan migas setiap provinsi di Indonesia dari tahun 2005 hingga tahun 2013. Gambar tersebut menunjukkan bahwa Provinsi Riau dan Provinsi Kalimantan Timur merupakan provinsi penghasil SDA minyak dan gas tertinggi di Indonesia. Sumbangan kedua provinsi tersebut mencapai sekitar 65 persen SDA migas di Indonesia.

\section{Gambar 1}

Kontribusi Minyak dan Gas dalam PDB Indonesia 2000-2013

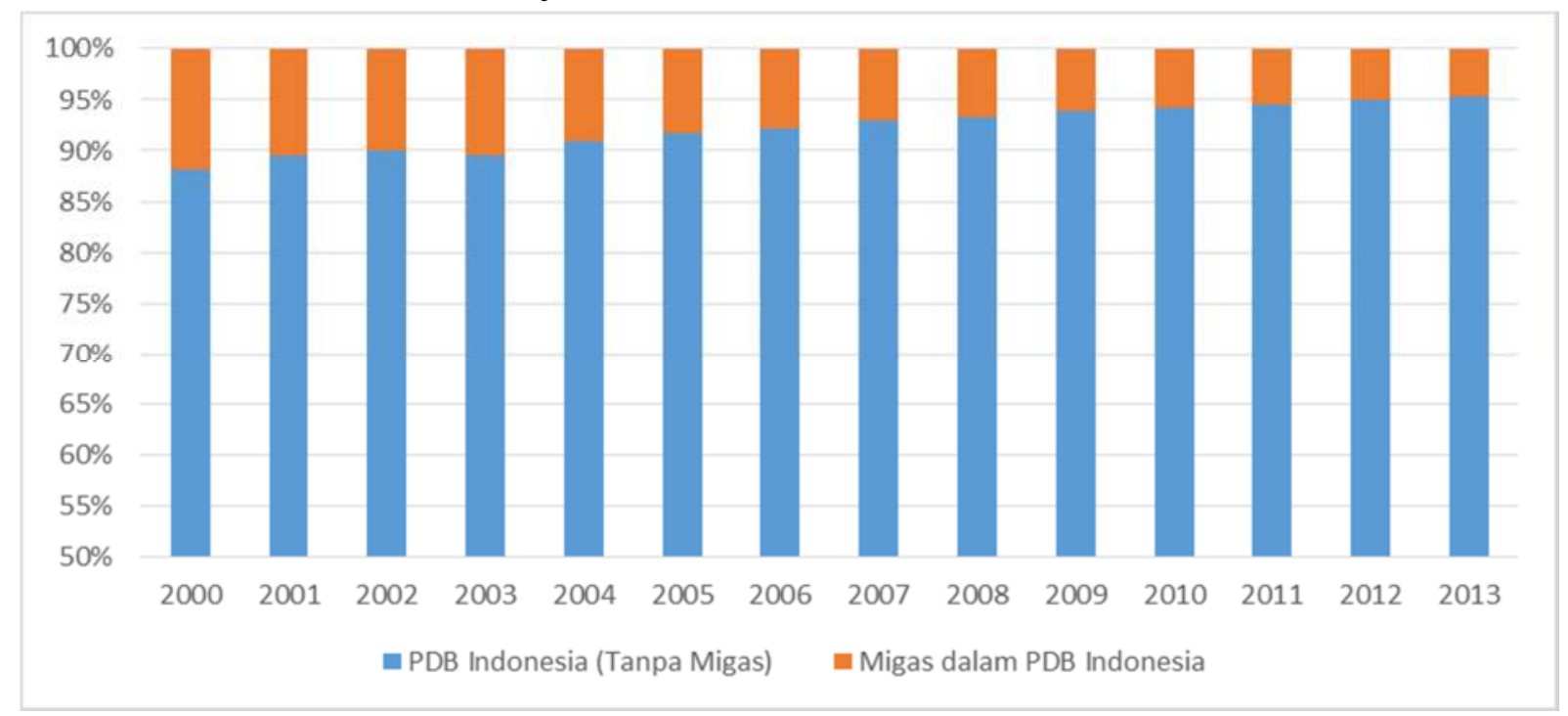

Sumber: Badan Pusat Statistik (2016, diolah)

Gambar 2

Rerata Kontribusi Sumbangan SDA Migas Setiap Provinsi Periode 2005-2013

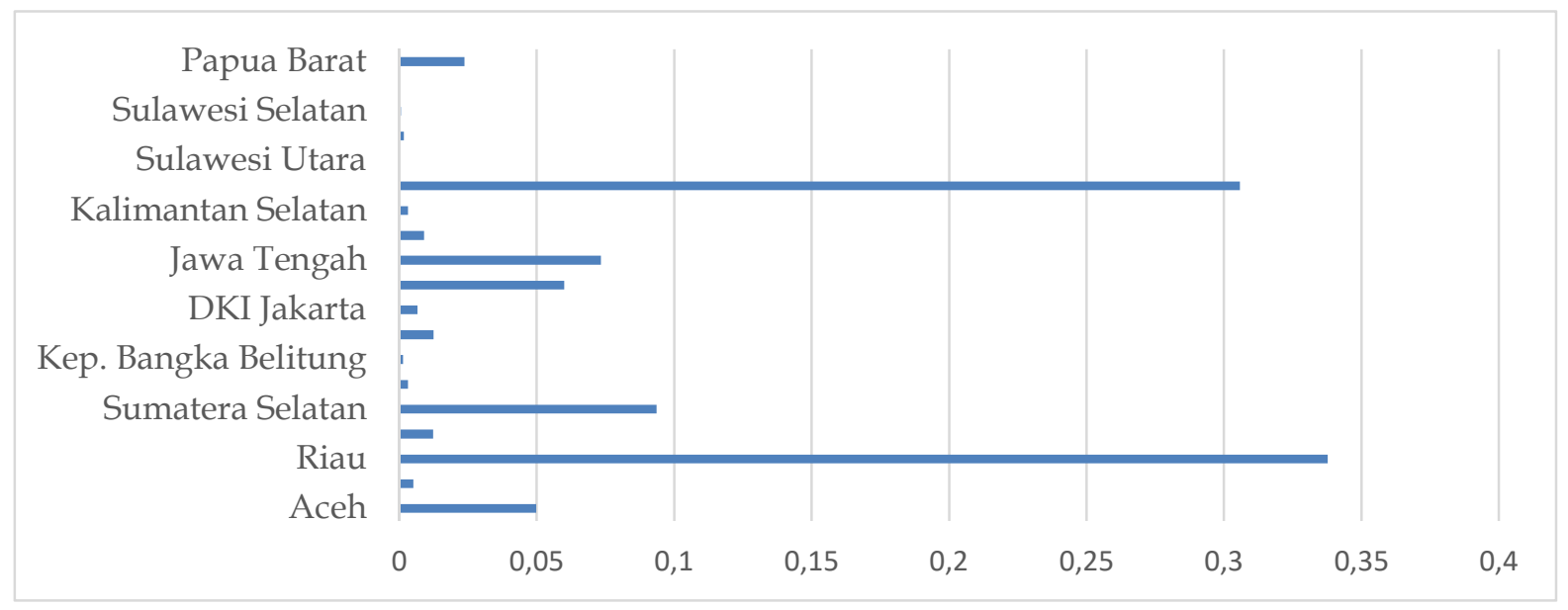

Sumber : Badan Pusat Statistik (2016, diolah)

Apabila dilihat lebih detail, kontribusi minyak dan gas yang terus menurun dalam PDB Indonesia lebih disebabkan karena terjadinya penurunan produksi minyak di
Indonesia. Pada tahun 2004, produksi minyak Indonesia masih berada pada kisaran 354 juta barel per tahun. Jumlah tersebut terus menurun hingga 25 persen 
pada tahun 2013, sehingga besarnya hanya mencapai 279 juta barel per tahun. Sementara itu dari sisi produksi gas, tren penurunan juga terjadi secara perlahan sejak tahun 2004. Kenaikan drastis mulai terjadi di tahun 2010 seiring dimulainya eksplorasi gas yang lebih masif sejak tahun 2009 di Ladang Gas Tangguh, Provinsi Papua Barat (informasi didasarkan pada data produksi gas yang dirilis oleh Kementerian ESDM). Namun produksi gas nasional pada tahun berikutnya kembali mengalami penurunan.

\section{Gambar 3}

\section{Produksi Minyak Mentah Indonesia 2004-2013}

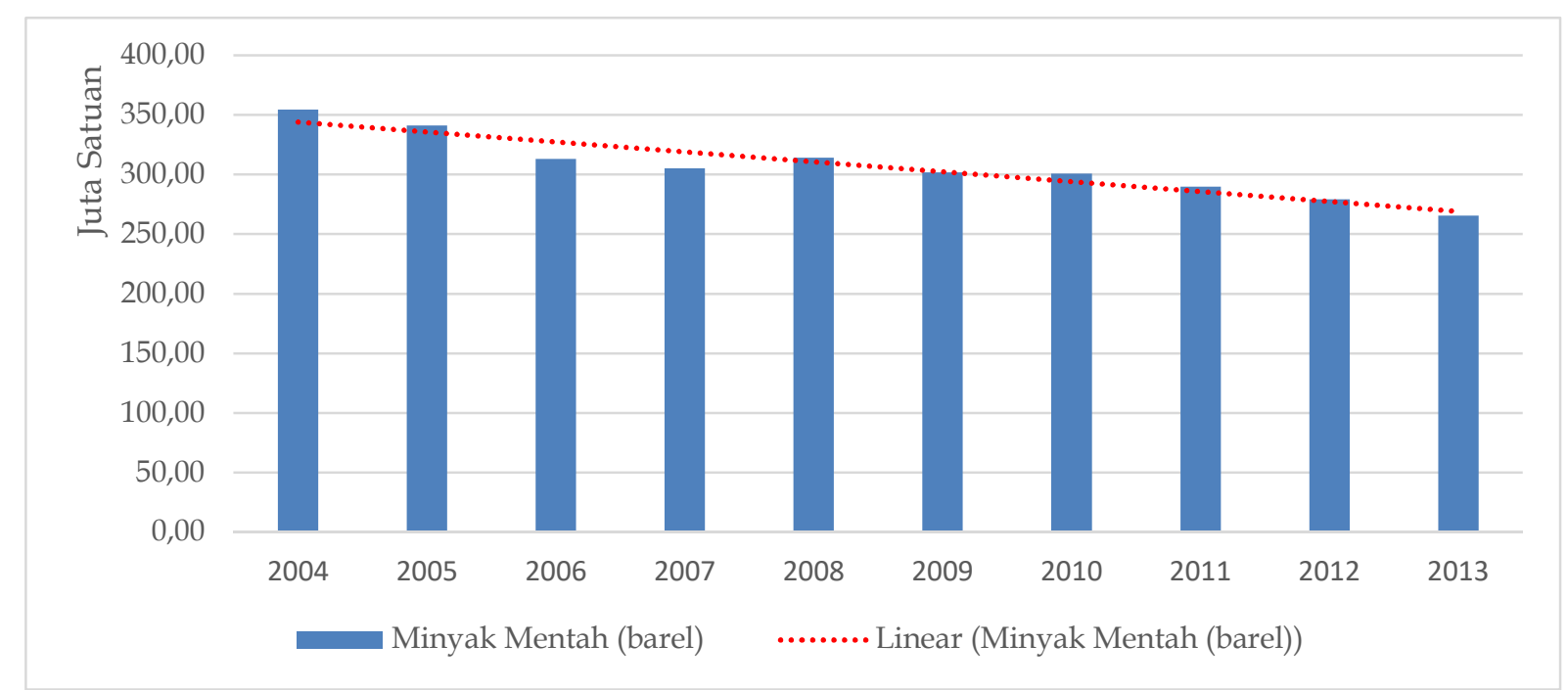

Sumber: Badan Pusat Statistik dan Kementrian ESDM (2016, diolah)

Gambar 4

Produksi Gas Alam Indonesia 2004-2013

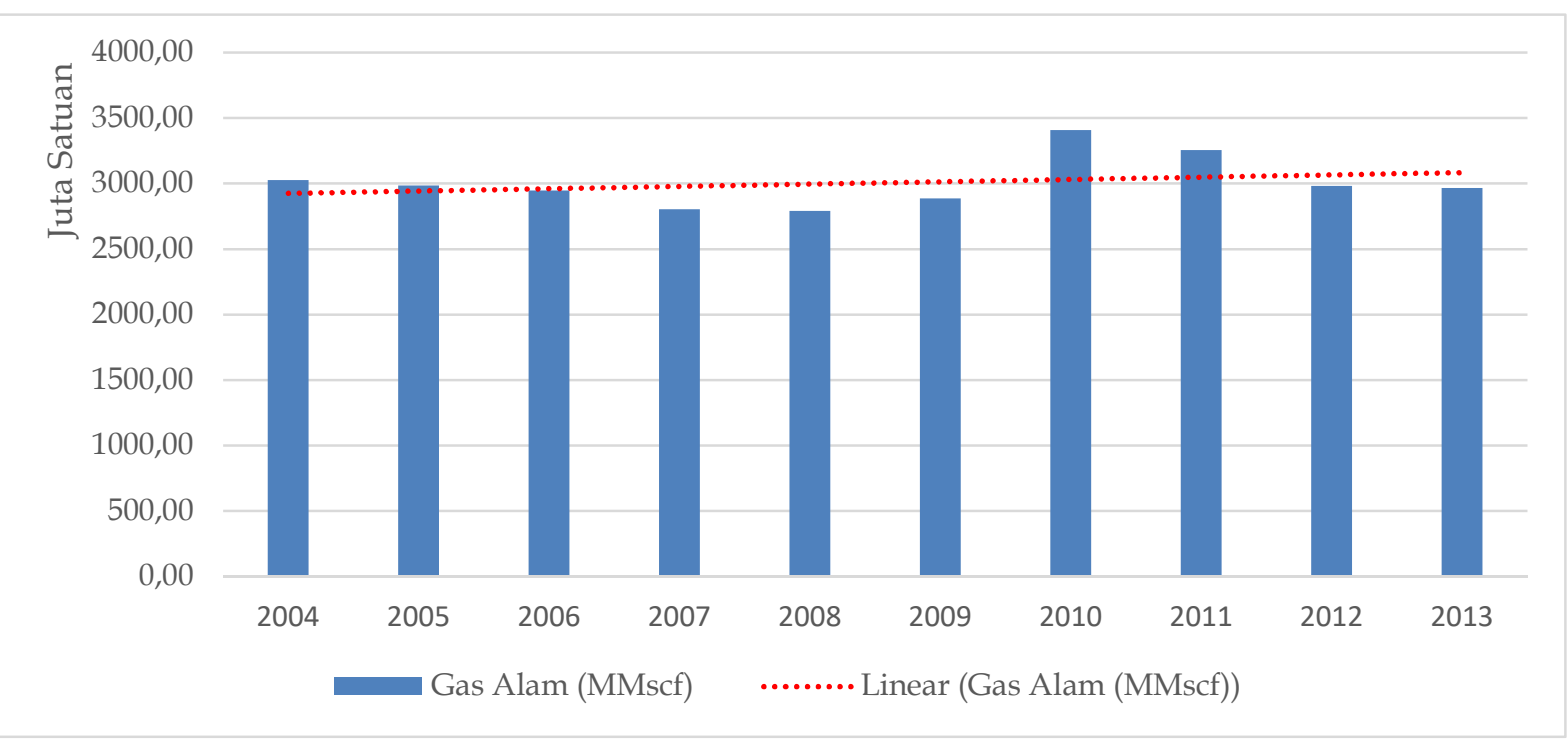

Sumber: Badan Pusat Statistik dan Kementrian ESDM (2016, diolah)

Penurunan produksi komoditas minyak dan gas dapat berimplikasi terhadap perlambatan pertumbuhan PDRB per kapita di provinsi yang memiliki ketergantungan terhadap SDA migas. Daerah yang memiliki ketergantungan minyak dan gas yang tinggi 
memiliki risiko terhadap volatilitas harga komoditas tersebut di pasar internasional. Gambar 5 memperlihatkan hubungan antara pertumbuhan ekonomi PDRB perkapita dan kekayaan minyak dan gas yang secara relatif cenderung negatif.

\section{Gambar 5}

Pertumbuhan PDRB per Kapita dan Kontribusi Migas 2006-2013

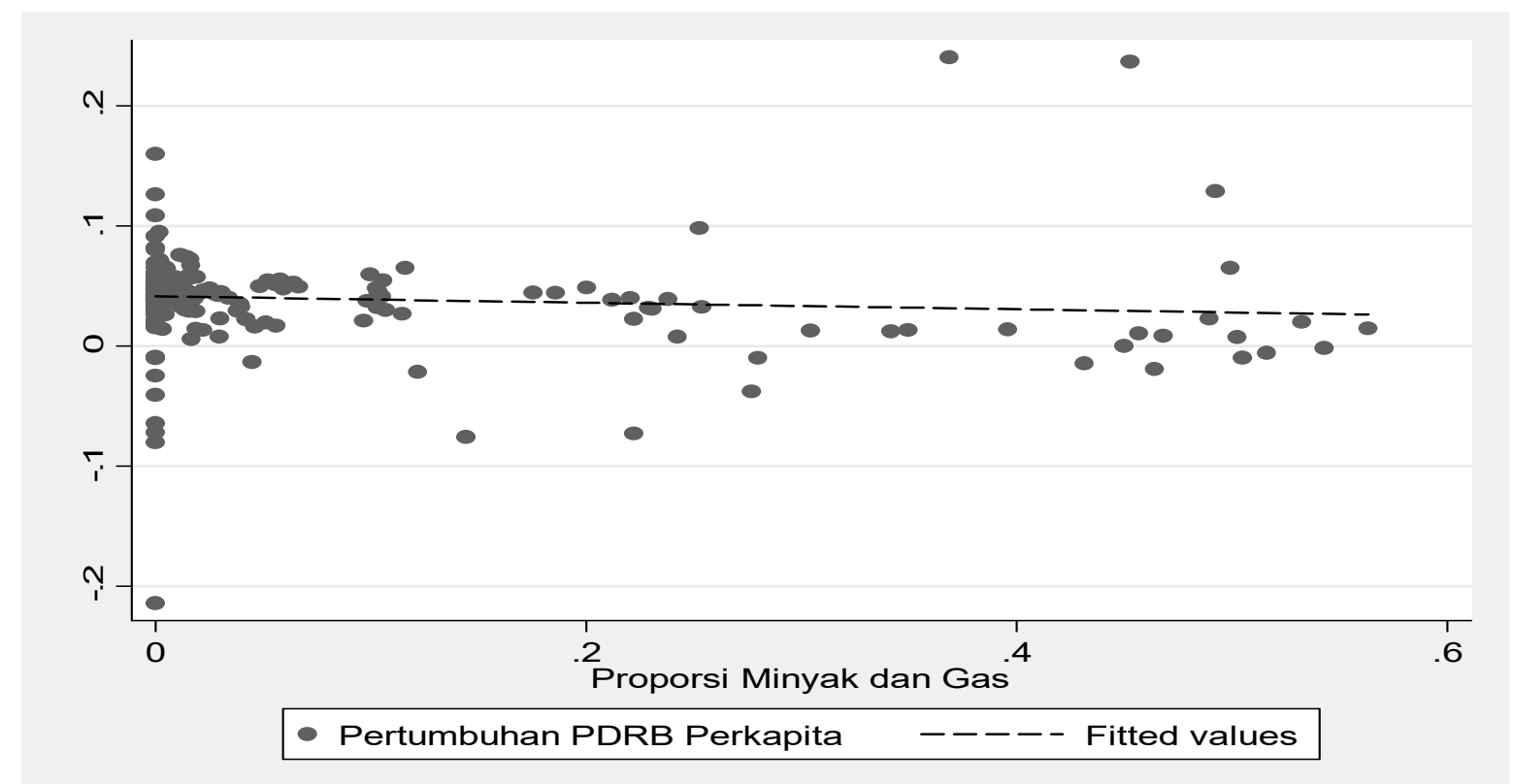

Sumber: Badan Pusat Statistik (2016, diolah)

Keberadaan minyak dan gas sebagai sektor produksi tentunya memiliki keterbatasan dalam jangka waktu pemanfaatan mengingat sumber daya alam ini akan semakin habis di masa depan. Untuk itu, penting kiranya untuk melihat bagaimana kinerja sektor-sektor selain minyak dan gas di daerah-daerah yang kaya akan minyak dan gas. Hal ini untuk memastikan bahwa sektor minyak dan gas dapat mendorong pertumbuhan sektor-sektor lain dalam jangka panjang.

Minyak dan gas sebagai salah satu SDA yang ketersediaannya berlimpah di beberapa provinsi seharusnya dapat menjadi motor pembangunan untuk meningkatkan kesejahteraan masyarakat. Amanat ini juga tertuang di dalam Pasal 33 Ayat 3 UndangUndang Dasar 1945 yang menyatakan bahwa bumi, air, dan kekayaan alam yang terkandung di dalamnya dikuasai oleh negara dan dipergunakan untuk sebesarbesarnya kemakmuran rakyat. Oleh karena itu, kegiatan eksplorasi dan produksi migas sudah seharusnya turut mempercepat peningkatan kesejahteraan khususnya masyarakat di mana SDA tersebut berada.

Berdasarkan penjelasan yang telah dikemukakan di atas, kekayaan sumber daya alam (SDA) tidak selalu dapat dimanfaatkan dengan baik oleh daerah yang memilikinya. Padahal, ketersediaan SDA khususnya migas, dapat menjadi modal kuat dalam pembangunan ekonomi. Indonesia sebagai negara yang memiliki SDA yang melimpah, khususnya minyak dan gas, mungkin saja dapat menjadi salah satu negara yang tidak dapat memanfaatkan ketersediaan SDA migas dengan baik. Distribusi SDA migas yang tidak merata antar-provinsi di Indonesia menjadi indikasi adanya perbedaan kinerja pertumbuhan antar-provinsi. Penelitian ini mencoba untuk melihat apakah terdapat perbedaan kinerja makroekonomi, yang diukur dengan pertumbuhan PDRB perkapita tanpa migas antar-provinsi yang 
memiliki perbedaan kekayaan akan komoditas minyak dan gas. Hal tersebut dapat mencerminkan bagaimana pengaruh kekayaan dari minyak dan gas terhadap sektorsektor lain dalam perekonomian suatu provinsi.

Penelitian empiris mengenai resource curse di Indonesia masih terbatas jumlahnya. Penelitian sebelumnya telah dilakukan oleh Komarulzaman dan Alisjahbana (2006) dengan menggunakan metode ordinary least square (OLS) dengan data rata-rata pertumbuhan PDRB per kapita sejak tahun 2000 hingga tahun 2004. Indikator kekayaan sumber daya alam yang digunakan dalam penelitian tersebut adalah natural resource rent. Penelitian lainnya yakni Rosser (2004) yang membahas secara kualitatif bagaimana Indonesia mengatasi fenomena kutukan sumber daya alam.

Penelitian ini mencoba untuk memperkaya literatur mengenai fenomena kutukan sumber daya alam di Indonesia antara lain dengan menggunakan indikator yang sedikit berbeda yaitu pertumbuhan PDRB per kapita tanpa migas antar-provinsi sebagai indikator pengukuran kinerja makroekonomi. Hal ini akan menunjukkan pengaruh kekayaan SDA terhadap sektor selain pertambangan minyak dan gas. Rentang waktu tahun 2006-2013 dipilih karena merupakan rentang waktu yang bebas dari adanya pembentukan provinsi baru dan memiliki nilai dasar perhitungan PDRB yang sama yaitu PDRB dengan tahun dasar 2000. Penelitian ini juga terdiri dari 33 provinsi yang merupakan populasi dalam rentang waktu yang dipilih tersebut.

Indikator kekayaan sumber daya alam minyak dan gas diukur dari kontribusi sektor pertambangan minyak dan gas terhadap PDRB dalam nilai riil tahun 2000. Selanjutnya, indikator kinerja makroekonomi diukur dengan pertumbuhan PDRB per kapita tanpa migas. Beberapa variabel lain yang digunakan sebagai kontrol yakni rasio pembentukan modal tetap bruto (PMTB) terhadap PDRB yang mewakili tingkat investasi, pengeluaran pemerintah terhadap PDRB yang mewakilkan tingkat kontribusi pengeluaran pemerintah, tingkat PDRB per kapita tanpa migas tahun sebelumnya yang mewakili nilai dari inisial pendapatan serta perubahan angka partisipasi murni yang mewakili perubahan modal manusia.

Transmisi pengaruh ketergantungan minyak dan gas dimulai dari perbedaan sumber daya alam yang dimiliki oleh setiap provinsi khususnya SDA migas. Provinsi yang memiliki ketergantungan terhadap minyak dan gas yang tinggi, tercermin dari porsi migas di dalam PDRB, akan mendapatkan dana bagi hasil dari pemerintah pusat sehingga menambah pendapatan pemerintah daerah. Pendapatan tersebut selanjutnya mempengaruhi belanja dan investasi di provinsi tersebut. Hal tersebut akan mempengaruhi pertumbuhan PDRB perkapita tanpa migas di dalam provinsi tersebut.

Selain melalui jalur tersebut, kegiatan ekstraksi migas juga akan menciptakan permintaan dari sektor pertambangan migas kepada sektor-sektor lainnya di dalam provinsi. Hal tersebut turut mendorong pertumbuhan PDRB perkapita tanpa migas di provinsi tersebut.

\section{TINJAUAN TEORETIS}

Model pertumbuhan Solow menunjukkan bagaimana pertumbuhan faktor-faktor produksi yaitu tenaga kerja, modal dan efisiensi teknologi mempengaruhi output dan tingkat produktivitas masyarakat dalam suatu perekonomian. Model pertumbuhan Solow mampu menjelaskan bagaimana terjadinya perbedaan produktivitas antar negara di dunia.

Penjelasan dalam model pertumbuhan solow, dimulai dari aspek penawaran yaitu sisi produksi. Dengan menggunakan fungsi produksi dengan dua jenis faktor produksi, diketahui bahwa persamaan produksinya sebagai berikut:

$Y=f(K, L)$

Solow mengasumsikan bahwa fungsi produksi di atas bersifat constant return to 
scale. Hal tersebut membuat analisis perubahan dalam faktor produksi lebih mudah dijelaskan dari sisi output. Apabila terjadi perubahan faktor produksi sebesar satu satuan pada kedua faktor produksi secara bersamaan, maka output akan berubah sebesar satu satuan pula. Dengan penjelasan di atas dan untuk melihat tingkat produktivitas setiap pekerja, maka seluruh variabel dalam fungsi produksi yang terdapat pada persamaan (1) tersebut dibagi dengan total pekerja sehingga fungsi produksi dapat dituliskan kembali sebagai berikut:

$\frac{Y}{L}=f\left(\frac{K}{L}, \frac{L}{L}\right)$

$\frac{Y}{L}=f\left(\frac{K}{L}, 1\right)$

$y=f(k)$

dengan y merupakan output per tenaga kerja dan $\mathrm{k}$ adalah modal yang digunakan oleh setiap pekerja. Berdasarkan persamaan di atas, diketahui bahwa fungsi dari output setiap pekerja dipengaruhi oleh tingkat modal yang digunakan oleh setiap pekerja. Slope dari persamaan tersebut menunjukkan tambahan output yang dihasilkan setiap pekerja ketika terdapat tambahan satu unit modal (marginal product of capital). Penambahan modal secara terus menerus akan memberikan tambahan output yang terus menurun atau bersifat diminishing. Secara matematika dituliskan dalam bentuk sebagai berikut:

$M P K=f^{\prime}(k)$

Selanjutnya disusun persamaan dari segi permintaan di mana diasumsikan hanya ada konsumsi dan investasi dalam perekonomian sehingga persamaannnya dapat dinyatakan dalam bentuk sebagai berikut:

$Y=C+I$

$\frac{Y}{L}=\frac{C}{L}+\frac{I}{L}$

$y=c+i$

Berdasarkan persamaan di atas diketahui bahwa $\mathrm{Y}$ adalah total permintaan dalam perekonomian, $\mathrm{C}$ adalah total konsumsi dan I adalah total investasi. Seluruh variabel dibagi dengan variabel pekerja (L) untuk melihat besaran setiap variabel relatif terhadap jumlah pekerja. Selanjutnya diketahui bahwa y adalah total permintaan setiap pekerja, $\mathrm{c}$ adalah total konsumsi untuk setiap pekerja dan i adalah total investasi untuk setiap pekerja.

Selanjutnya diketahui bahwa konsumsi per pekerja merupakan total pendapatan per pekerja dikurangi dengan tabungan per pekerja (s) sehingga investasi untuk setiap pekerja sama dengan tabungan untuk setiap pekerja. Kemudian persamaan konsumsi pekerja tersebut digunakan dalam persamaan 8 sehingga didapatkan persamaan sebagai berikut:

$y=c+s$

$y=(1-s) y+i$

sy $=i$

$s f(k)=i$

Selanjutnya diketahui bahwa investasi digunakan untuk menambah jumlah modal dan mengganti modal sebelumnya yang telah mengalami depresiasi sehingga ditemukan persamaan sebagai berikut:

$\Delta k=i+\delta k$

dengan $\Delta k$ merupakan perubahan kapital dan $\delta$ merupakan tingkat depresiasi kapital. Kemudian untuk melihat tingkat output per pekerja dalam kondisi steady state (kondisi ketika output per pekerja tetap telah mencapai keseimbangan) maka persamaannya dinyatakan sebagai bentuk berikut: $\Delta k=0$

$s f(k)=\delta k$

Berdasarkan persamaan tersebut diketahui bahwa kondisi steady state terjadi ketika tingkat modal per pekerja tidak lagi mengalami perubahan sehingga pertumbuhan akan terus terjadi selama jumlah investasi melebihi jumlah modal yang terdepresiasi. Dari seluruh persamaan di atas diketahui bahwa tingkat modal memberikan peran penting dalam meningkatkan produktivitas pekerja sehingga semakin tinggi 
tingkat tabungan akan memberikan jumlah modal yang lebih besar sehingga pekerja bisa lebih produktif (Mankiw, 2012).

Sumber daya alam minyak dan gas (SDA migas) termasuk sumber daya alam yang tidak dapat diperbaharui. Pembentukan SDA migas di bumi membutuhkan proses yang memakan waktu hingga jutaan tahun. Hal tersebut berimplikasi pada ketersediaan SDA migas yang langka dan tersebar. Hal tersebut menyebabkan SDA migas memiliki nilai ekonomis yang cukup tinggi.

Sumber daya alam berupa minyak dan gas sebagai sumber energi memiliki peran penting dalam perekonomian. Berdasarkan fungsi pertumbuhan Solow yang telah dijelaskan sebelumnya, diketahui bahwa output merupakan fungsi dari tenaga kerja (L) dan modal (K). Kemudian variabel energi (E) dapat ditambahkan sebagai salah satu faktor produksi dalam perekonomian. Dengan ketiga variabel memiliki pengaruh positif terhadap output sehingga setiap penambahan jumlah energi, maka akan terjadi penambahan jumlah output. Dalam bentuk matematis, dapat dinyatakan dalam bentuk:

$Y=f(K, L, E)$

$\frac{\partial Y}{\partial K}>0 ; \frac{\partial Y}{\partial L}>0 ; \frac{\partial Y}{\partial E}>0$

Sebagai daerah yang memiliki SDA migas, komoditas tersebut memberikan dua manfaat sekaligus, yaitu sebagai sumber pendapatan bagi daerah tersebut melalui penjualan SDA migas serta sebagai sumber energi bagi kegiatan produksi daerah tersebut. Peningkatan pendapatan yang berasal dari penjualan migas dapat menjadi sumber tambahan modal untuk investasi, sehingga dapat meningkatkan pertumbuhan ekonomi di masa depan. Berdasarkan penjelasan tersebut, dapat disimpulkan bahwa keberadaan sumber daya alam dapat menjadi motor pendorong pertumbuhan ekonomi.

Desentralisasi fiskal pasca reformasi telah memberikan kesempatan kepada pemerintah daerah untuk memberdayakan potensi-potensi daerah. Postur Anggaran Pendapatan dan Belanja Negara (APBN) sejak saat itu diisi dengan pos transfer ke daerah yang di dalamnya termasuk kebijakan dana perimbangan. Kebijakan dana perimbangan merupakan kebijakan dengan melakukan transfer dana yang bersumber dari APBN ke daerah, berupa dana bagi hasil (DBH), dana alokasi umum (DAU), dan dana alokasi khusus (DAK).

Berdasarkan definisinya, DBH adalah dana yang bersumber dari APBN yang dialokasikan untuk daerah berdasarkan angka persentase tertentu untuk mendanai kebutuhan daerah dalam rangka pelaksanaan desentralisasi. DBH merupakan sumber pendapatan bagi daerah dengan besaran yang ditentukan berdasarkan sumbangan setiap daerah terhadap pendapatan APBN Indonesia.

Salah satu jenis dana bagi hasil dalam APBN adalah dana bagi hasil sumber daya alam minyak dan gas. Aturan mengenai pembagian dana bagi hasil sumber daya alam migas tercantum dalam UndangUndang Nomor 33 Tahun 2004 tentang Perimbangan Keuangan antara Pemerintah Pusat dan Pemerintah Daerah serta Peraturan Pemerintah Nomor 55 Tahun 2005 tentang Dana Perimbangan.

Kekayaan sumber daya alam kenyataannya tidak selalu dapat dimanfaatkan dengan baik, sehingga muncul sebuah istilah yang disebut natural resource curse atau kutukan sumber daya alam. Menurut Ross (2015), fenomena kutukan sumber daya alam adalah efek negatif kekayaan sumber daya alam terhadap keadaan ekonomi, politik dan sosial. Paradoks mengenai kutukan sumber daya alam pertama kali diangkat oleh Auty (1994) yang menemukan bahwa negaranegara dengan sumber daya alam yang melimpah mengalami pertumbuhan ekonomi yang lebih lambat. Hipotesis mengenai kutukan sumber daya alam semakin diperkuat oleh penelitian yang dilakukan oleh Sachs dan Warner (1995) yang menemukan bahwa semakin tinggi rasio ekspor SDA 
terhadap PDB pada suatu negara, maka cenderung akan memiliki pertumbuhan ekonomi yang lebih rendah.

Beberapa hal berikut merupakan argumen terkait penyebab fenomena kutukan sumber daya alam yang diambil dari buku "escaping the resource curse" (Humphreys et al., 2007), yaitu:

1. Dutch Disease

Model Dutch disease merupakan konsep yang menjelaskan bagaimana pengaruh negatif aktivitas eksploitasi SDA terhadap perekonomian. Pada model Dutch disease diasumsikan terdapat 3 sektor dalam perekonomian yaitu sektor sumber daya alam yang tradeable, sektor manufaktur yang tradeable, dan sektor lainnya yang nontradeable. Besarnya sumber daya alam yang dimiliki membuat sektor sumber daya alam yang tradeable menjadi tumbuh pesat sehingga meningkatkan pendapatan masyarakat. Sementara itu, dampak pertumbuhan di sektor SDA menyebabkan nilai tukar riil negara tersebut mengalami apresiasi sehingga sektor manufaktur menjadi tidak kompetitif. Hal ini membuat input produksi, tenaga kerja, dan modal, beralih dari sektor manufaktur ke sektor SDA maupun sektor lainnya yang non-tradeable. Hal tersebut menyebabkan negara mengalami deindustrialisasi.

Dampak yang ditimbulkan akibat terjadinya deindustrialisasi adalah hilangnya sumber pertumbuhan jangka panjang yang umumnya terdapat pada sektor manufaktur, seperti perkembangan teknologi dan kualitas pekerja, sehingga terjadinya deindustri alisasi dapat menyebabkan terjadinya perlambatan ekonomi di masa mendatang (Sachs dan Warner, 2001). Selain itu pergeseran sektor tersebut juga membuat distribusi pendapatan menjadi tidak merata sehingga menciptakan ketimpangan yang relatif lebih tinggi.

\section{Volatilitas}

Sumber daya alam berupa minyak dan gas yang berlimpah pada suatu daerah tentu menjadi berkah bagi pemasukan daerah tersebut. Namun pemasukan dari sumber daya alam migas memiliki risiko yaitu volatilitas dari pendapatan SDA migas tersebut. Volatilitas tersebut setidaknya berasal dari kecepatan ekstraksi migas antar-waktu, fluktuasi harga SDA migas, serta jadwal pembagian hasil ekstraksi migas antara perusahaan dan negara.

Kecepatan ekstraksi migas cenderung memiliki tren negatif dari waktu ke waktu. Volume ekstraksi migas mencapai puncak pada masa awal kegiatan ekstraksi (frontloading). Hal ini membuat nilai riil pendapatan yang berasal dari migas cenderung akan terus menurun dari waktu ke waktu.

Permasalahan fluktuasi harga SDA migas juga memberikan pengaruh ketidak pastian pendapatan pada daerah penghasil migas. Hal tersebut membuat fluktuasi pada kegiatan investasi dan belanja pemerintah sehingga kegiatan ekonomi daerah tersebut memiliki unsur ketidakpastian yang justru dapat menimbulkan dampak negatif bagi kestabilan ekonomi.

3. Kegagalan Penggunaan Pendapatan Sumber Daya Alam

Potensi masalah berikutnya terjadi akibat kegagalan pemerintah dalam membelanjakan pendapatan dari sumber daya alam. Migas merupakan sumber daya alam yang akan habis. Pendapatan sumber daya alam seharusnya dipandang sebagai penggunaan modal sehingga pendapatan tersebut seharusnya diarahkan pada belanja modal yang lebih produktif.

\section{Investasi Pendidikan yang Tidak Memadai}

Negara yang memiliki kekayaan sumber daya alam cenderung memiliki investasi pendidikan yang rendah. Hal tersebut dikarenakan negara bergantung kepada sektor sumber daya alam yang cenderung memiliki kebutuhan tenaga kerja terampil yang rendah. Sedangkan pembangunan ekonomi yang lebih bersifat jangka panjang, seperti pada sektor manufaktur dan jasa, membutuhkan investasi pada tenaga kerja. Pendapatan yang berasal dari sumber daya 
alam secara terus menerus membuat pemerintah kurang fokus dalam pembangunan sumber daya manusia.

Penjelasan lainnya mengenai resource curse diajukan oleh Torvik (2002) dan menyatakan bahwa berlimpahnya sumber daya alam mendorong terjadinya peningkatan aktivitas rent-seeking. Hal ini menyebabkan turunnya kegiatan produktif di sektor industri. Sementara itu, Gylfason (2001) menyatakan bahwa cadangan SDA yang besar dapat membuat negara terlalu percaya diri sehingga mengurangi sensitivitas untuk merespon kebijakan.

Selanjutnya, Boschini et al. (2007) secara implisit menyatakan bahwa salah satu faktor terjadinya kutukan sumber daya alam, dalam penelitian ini adalah penelitian terkait dengan mineral, adalah keberadaan institusi di negara tersebut. Apabila negara tersebut memiliki kualitas institusi yang bagus, sumber daya alam dapat memberikan pengaruh positif dalam perekonomian. Temuan tersebut juga didukung oleh penelitian yang dilakukan oleh Mehlum et al. (2006). Dalam studi kasusnya, Pick dan Thein (2010) juga menunjukkan bahwa kegagalan pembangunan di Myanmar karena adanya perilaku rezim korup dan tidak kompeten yang menyalahgunakan hasil dari kekayaan mineral dan energi yang besar di negara tersebut.

Collier dan Hoeffler (1998) menyatakan bahwa kegiatan produksi sumber daya alam cenderung memicu konflik sosial. Argumen ini diperkuat oleh penelitian Brunnscheweiler dan Bulte (2009). Peningkatan risiko konflik sosial tersebut dapat terjadi apabila ada penemuan SDA baru ketika stok atau produksi SDA sebelumnya sedang rendah. Risiko konflik sosial tersebut senada dengan penelitian Hodler (2006) yang menyatakan bahwa banyaknya golongan/etnis dalam daerah menyebabkan negara kaya sumber daya alam cenderung lebih miskin.

Telah banyak literatur yang melakukan penelitian mengenai fenomena kutukan sumber daya alam. Perdebatan mengenai apakah kutukan sumber daya alam memang ada atau hanya sebuah mitos masih terus berlanjut. Beberapa penelitian sebelumnya masih belum mencapai konsensus apakah kutukan sumber daya alam itu bersifat universal atau hanya terjadi di sebagian wilayah. Beberapa penelitian yang terkait dengan fenomena kutukan sumber daya alam, diantaranya adalah Sachs dan Warner (1995), Gylfason (2001), Papyrakis dan Gerlagh (2007), Davis (2011), James dan James (2011), Murshed dan Serino (2011), Cavalcanti et al. (2011), Fan et al. (2012), Bjorvatn et al. (2012), dan Komarulzaman dan Alisjahbana (2006).

Penelitian yang telah dilakukan oleh Sachs dan Warner (1995) menemukan bahwa terdapat hubungan negatif antara kekayaan sumber daya alam dan pertumbuhan ekonomi. Berdasarkan penelitian ini, kecepatan pertumbuhan ekonomi di negara yang kaya akan SDA lebih lambat dibandingkan dengan negara yang miskin SDA. Penelitian ini mencakup 95 negara dengan menggunakan data dari tahun 1970-1989. Perhitungan kekayaan SDA dalam penelitian ini berdasarkan rasio ekspor SDA terhadap PDB. Penemuan ini mendukung eksistensi dari fenomena kutukan sumber daya alam.

Selanjutnya, Gylfason (2001) melakukan penelitian lebih lanjut mengenai kekayaan sumber daya alam dan pembangunan ekonomi. Penelitian ini menemukan bahwa kekayaan sumber daya alam berhubungan negatif dengan pertumbuhan ekonomi, penelitian ini menyatakan bahwa pengaruh negatif terhadap pertumbuhan ekonomi lebih disebabkan oleh penurunan modal manusia yang diukur dengan angka partisipasi sekolah.

Sementara itu, Papyrakis dan Gerlagh (2007) melakukan penelitian mengenai hipotesis resource curse dengan menggunakan data negara bagian di Amerika Serikat selama periode 1986-2001. Penelitian ini menggabungkan investasi, pendidikan, korupsi, dan keterbukaan perdagangan dalam model pertumbuhannya. Hasil penelitian tersebut menunjukkan bahwa kekayaan sumber daya alam dan korupsi menghambat 
pertumbuhan ekonomi. Davis (2011) melakukan penelitian lebih lanjut mengenai resource curse dengan model yang menggambarkan perlambatan industri dan menyebabkan perlambatan perekonomian secara keseluruhan. Dengan menggunakan data dalam periode 1971-1990. Penelitian ini menemukan bahwa terdapat hubungan negatif antara ketergantungan SDA dengan pertumbuhan ekonomi.

Kemudian, James dan James (2011) me lakukan penelitian pada tingkat subnasional di Amerika. Penelitian ini menemukan hubungan negatif antara pertumbuhan ekonomi dan ketergantungan terhadap sektor pertambangan. Namun hal ini dikarenakan perlambatan sektor pertambangan itu sendiri.

Murshed dan Serino (2011) melakukan penelitian terkait dengan spesialisasi negara dan pertumbuhan ekonomi. Dengan menggunakan data 49 negara dalam kurun waktu 1960-2005, penelitian ini menemukan bahwa negara yang gagal melakukan diversifikasi struktur ekspor dan juga struktur ekonomi akan mengalami hambatan dalam pertumbuhan ekonomi.

Selanjutnya, Cavalcanti et al. (2011) melakukan penelitian mengenai pengaruh kekayaan alam yang dihitung melalui tiga pendekatan yaitu produksi minyak, oil rents, dan cadangan terhadap pendapatan riil. Dengan menggunakan data dari 53 negara selama kurun waktu 1980-2006, penelitian ini menemukan bahwa kekayaan alam berhubungan positif dengan pendapatan riil dalam jangka pendek maupun dalam jangka panjang.

Fan et al. (2012) melakukan penelitian mengenai eksistensi kutukan sumber daya alam di China. Hasil penelitian menunjukkan bahwa fenomena resource curse tidak terjadi di Negara China secara keseluruhan. Namun, penelitian ini menemukan bahwa setiap kota yang terletak di dekat kota yang kaya akan sumber daya alam mendapatkan dampak ekonomi yang positif yang masih dalam lingkup satu provinsi. Sementara itu, Bjorvatn et al. (2012) melakukan penelitian untuk melihat fenomena kutukan sumber daya alam dari aspek politik. Dengan menggunakan data panel dari 30 negara kaya akan minyak, penelitian ini menemukan bahwa peran kekuatan fraksi dalam pemerintahan memegang peranan penting dari manfaat sumber daya alam. Dengan pemerintah yang memiliki kekuatan politik yang besar, maka sumber daya alam dapat mendorong pertumbuhan ekonomi meskipun secara institusi masih terbelakang.

Untuk kasus Indonesia, Komarulzaman dan Alisjahbana (2006) menggunakan metode estimasi OLS dengan data rata-rata pertumbuhan PDRB per kapita setiap kabupaten/kota sejak tahun 2000 hingga 2004. Indikator kekayaan sumber daya alam yang digunakan dalam penelitian tersebut adalah natural resource rent atau pendapatan dari bagi hasil pemerintah daerah atas kegiatan ekstraksi migas di daerah tersebut. Penelitian ini mengisyaratkan bahwa ada efek positif dari sektor perkebunan dan migas namun terdapat efek negatif dari sektor pertambangan lainnya.

Indikator untuk menentukan kekayaan sumber daya alam memiliki banyak variasi. Sachs dan Warner (1995) menggunakan rasio ekspor komoditas minyak mentah terhadap pendapatan nasional. Sementara itu, Atkinson dan Hamilton (2003) menggunakan rasio pendapatan bersih migas terhadap PDB sebagai indikator kekayaan sumber daya alam. James (2015) menggunakan rasio produksi sumber daya alam terhadap PDB.

Menurut Ross (2015), ada tiga komponen utama yang digunakan untuk menyusun besaran kekayaan alam suatu daerah yaitu jenis sumber daya alam, unit pengukuran sumber daya alam dan metode yang digunakan untuk menstabilkan nilai indikator tersebut. Jenis sumber daya alam yang dimaksud seperti minyak, gas, pertambangan, pertanian, emas, berlian dan lainnya. Sedangkan unit pengukuran yang dimaksud seperti nilai produksi, total penjualan, nilai ekspor dan lainnya. Untuk metode pengukuran indicator, umumnya digunakan nilai relatif terhadap PDB, total ekspor, total 
pendapatan pemerintah dan lainnya. Kombinasi tersebut menciptakan banyak indikator pengukuran kekayaan sumber daya alam. Namun tidak ada satu metode yang dianggap sebagai pengukuran terbaik. Pengukuran yang digunakan bergantung pada tujuan masing-masing penelitian. Dengan berbagai variasi yang ada, indikator kekayaan alam yang digunakan dalam penelitian ini serupa dengan yang digunakan oleh James (2015) di mana besarannya merupakan kontribusi total produksi sektor pertambangan migas relatif terhadap PDRB (selanjutnya variabel ini disingkat dengan MG).

Selanjutnya untuk melihat pengaruh ketergantungan migas terhadap perekonomian, mengadaptasi penjelasan yang dilakukan oleh James dan James (2011) dalam karyanya yaitu "Do resource dependent regions grow slower than they should?", diasumsikan bahwa perekonomian memiliki dua sektor yaitu sektor SDA migas dan sektor bukan SDA migas. Dengan demikian, dapat diungkapkan suatu bentuk persamaan seperti terlihat pada persamaan (18) sebagai berikut: $\mathrm{Y}=$ Migas + Bukan Migas

dengan $\mathrm{Y}$ merupakan total output dalam perekonomian. Selanjutnya, apabila dalam persaman (18) masing-masing komponen dinyatakan dalam bentuk pertumbuhan per kapita, maka dapat dinyatakan dalam bentuk sebagai berikut:

$G=g^{\text {migas }}+$ gnonmigas

dengan $G$ merupakan pertumbuhan PDRB per kapita secara keseluruhan. Sedangkan gmigas merupakan sumbangan pertumbuhan PDRB per kapita dari sektor migas dan gnonmigas merupakan sumbangan pertumbuhan per kapita dari sektor selain migas. Dengan nilai MG sebagai tingkat ketergantungan migas, maka hubungan antara variabel MG dan gnonmigas menunjukkan apakah ketergantungan terhadap minyak dan gas menjadi kutukan atau anugerah bagi pertumbuhan sektor selain migas. Berdasarkan literatur yang telah disampaikan di atas, kerangka pemikiran atas penelitian ini adalah: (i) minyak dan gas merupakan komoditas yang sangat bernilai untuk dijual dan juga merupakan komponen utama penghasil energi; (ii) keberadaan minyak dan gas memberikan pendapatan bagi masyarakat tersebut serta pemerintah daerah sehingga mempengaruhi konsumsi masyarakat dan pengeluaran pemerintah. Kedua variabel tersebut akan mempengaruhi variabel PDB atau pertumbuhan ekonomi; dan (iii) keberadaan minyak dan gas juga merupakan sumber energi dalam mendorong aktivitas ekonomi. Keberadaan minyak dan gas tersebut menjadi faktor produksi yang akan mempengaruhi sisi penawaran agregat sehingga dapat mempengaruhi variabel PDB atau pertumbuhan ekonomi.

Merujuk berbagai penjelasan yang telah diuraikan di atas, secara konseptual model ekonometrika yang dikembangkan dalam studi ini dapat dinyatakan dalam bentuk:

$\mathrm{g}^{\text {nonmigas }}=\mathrm{f}(\mathrm{MG}, \mathrm{Z})$

Persamaan (20) menjelaskan bahwa pertumbuhan PDRB per kapita dari sektor bukan migas dipengaruhi oleh keter gantungan akan migas dan variabel lainnya yang meliputi tingkat modal manusia, pembentukan modal tetap, dan pengeluaran pemerintah. Selanjutnya, adapun hipotesis yang dikembangkan pada penelitian ini adalah kekayaan migas memiliki pengaruh terhadap pertumbuhan PDRB per kapita tanpa migas di Indonesia.

\section{METODE PENELITIAN}

Model empiris dalam penelitian ini mengadopsi model yang dikembangkan oleh Barro (2003) yang berjudul "Determinants of Economic Growth in a Panel of Countries" dengan penggunaan beberapa variabel berdasarkan ketersediaan data di tingkat provinsi. Model tersebut menjadi dasar bagi model determinan pertumbuhan ekonomi pada penelitian ini dengan penambahan variabel kontribusi minyak dan gas terhadap PDRB sebagai variabel 
utama dalam penelitian ini. Berdasarkan penjelasan di atas, maka model yang diajukan dalam penelitian ini adalah sebagai berikut:

$\mathrm{G}_{\mathrm{i}, \mathrm{t}}=\alpha_{0}+\beta_{1} \mathrm{MG}_{i, t}+\beta_{2} \Delta \mathrm{APM}_{i, t}+\beta_{3} \mathrm{PMTB}_{i, t-1}+$ $\beta_{4} \mathrm{PP}_{i, t}+\beta_{5} \operatorname{LnPDRB}_{i, t-1}+\varepsilon_{i, t}$

dengan $\alpha$ adalah suatu konstanta; $\beta$ merupakan koefisien regresi setiap variabel bebas; $G$ adalah pertumbuhan PDRB per kapita (persen) tanpa migas; MG merupakan kontribusi minyak dan gas terhadap PDRB (persen); $\triangle \mathrm{APM}$ menunjukkan perubahan angka partisipasi murni (persen); PMTB $_{\mathrm{t}-1}$ adalah rasio pembentukan modal tetap bruto terhadap PDRB (persen) tahun sebelumnya; PP merupakan rasio pengeluaran pemerintah terhadap PDRB (persen); LnPDRB $_{\mathrm{t}-1}$ adalah PDRB per kapita tanpa migas pada tahun sebelumnya yang dinyatakan dalam logaritma natural; i merupakan individu (provinsi); $\mathrm{t}$ adalah waktu (tahun); dan $\varepsilon$ adalah Error Term.

Definisi operasional variabel pada penelitian ini adalah sebagai berikut:

a. Pertumbuhan PDRB per Kapita

Produk Domestik Regional Bruto (PDRB) per kapita yang digunakan dalam penelitian ini adalah produk domestik regional bruto (PDRB) per kapita tanpa migas dalam harga konstan tahun 2000. PDRB per kapita tanpa migas dihitung dengan cara membagi nilai PDRB tanpa migas dengan jumlah penduduk dalam satu tahun. Indikator ini diwakilkan oleh variabel G. Variabel PDRB perkapita tanpa migas dipilih untuk dapat membandingkan pertumbuhan sektor-sektor ekonomi yang sama antar-provinsi dengan mengeluarkan sektor minyak dan gas setiap provinsi tersebut.

b. Kontribusi Minyak dan Gas terhadap PDRB

Kontribusi Minyak dan Gas terhadap PDRB dalam nilai riil tahun 2000 digunakan sebagai proksi dari besaran kekayaan SDA migas yang diekstraksi dalam setahun di setiap provinsi.
Semakin besar nilai tersebut, maka semakin besar pula jumlah relatif sektor minyak dan gas dibandingkan sektorsektor lain dalam suatu provinsi. Variabel tersebut juga menunjukkan besarnya ketergantungan satu provinsi terhadap SDA minyak dan gas. Indikator ini diwakilkan oleh variabel MG.

c. Tingkat Modal Manusia

Tingkat modal manusia dalam penelitian ini diukur dengan data angka partisipasi murni (APM) tingkat SMA yang bersumber dari BPS. Tingkat SMA dipilih dikarenakan kebijakan pendidikan di Indonesia yang mayoritas hanya mewajibkan pendidikan hingga tingkat SMP (wajib belajar 9 tahun). Dengan begitu, perbandingan data antarprovinsi dapat semakin beragam. Data ini ditransformasikan dengan cara difference antar waktu, untuk melihat pengaruh perubahan tingkat modal manusia terhadap pertumbuhan PDRB per kapita. Indikator ini diwakilkan oleh variabel $\triangle \mathrm{APM}$.

d. Rasio Pembentukan Modal

Rasio pembentukan modal dihitung dengan cara membagi jumlah pembentukan modal tetap bruto (PMTB) terhadap total PDRB dalam nilai riil tahun 2000. Berdasarkan fungsi pertumbuhan solow, modal (capital) merupakan variabel penting dalam mendorong pertumbuhan produktivitas pekerja melalui besaran investasi yang akan mendorong jumlah modal yang dimiliki suatu provinsi. Variabel ini menggunakan lag 1 tahun dikarenakan adanya asumsi manfaat dari investasi dirasakan pada tahun mendatang. Indikator ini diwakilkan oleh variabel PMTB $_{\mathrm{t}-1 \text {. }}$.

e. Rasio Pengeluaran Pemerintah

Rasio ini menunjukkan kontribusi pengeluaran pemerintah terhadap PDRB. Pengeluaran pemerintah dihitung dengan cara membagi jumlah pengeluaran pemerintah terhadap total PDRB dalam 
nilai riil tahun 2000. Indikator ini diwakilkan oleh variabel PP.

f. Kondisi Inisial PDRB per Kapita

Berdasarkan teori pertumbuhan neoklasik, pertumbuhan ekonomi memiliki sifat diminishing. Artinya bahwa, provinsi dengan pendapatan awal yang relative sudah tinggi cenderung memiliki pertumbuhan yang melambat. Kondisi awal dalam penelitian ini diukur dengan besaran PDRB per kapita tanpa migas dalam nilai riil tahun 2000 pada periode sebelumnya lalu ditransformasikan dalam bentuk logaritma natural. Indikator ini diwakilkan oleh variabel $\mathrm{LnPDRB}_{\mathrm{t}-1}$.

Fokus dalam penelitian ini adalah melihat hubungan antara pertumbuhan PDRB per kapita tanpa migas dengan tingkat ketergantungan provinsi terhadap SDA migas. Oleh karena itu, penjelasan hasil akan difokuskan pada variabel MG sebagai variabel utama dalam penelitian. Sedangkan variabel lainnya merupakan variabel kontrol untuk menjaga konsistensi hubungan antara variabel MG dengan pertumbuhan PDRB per kapita tanpa migas.

Jenis data dalam penelitian ini merupakan data sekunder berupa data panel dengan jumlah 33 provinsi dan rentang waktu 2005-2013. Seluruh data berasal dari
Badan Pusat Statistik. Keseluruhan data terkait dengan PDRB yang diambil dari Badan Pusat Statistik menggunakan harga konstan tahun 2000.

Setidaknya, terdapat tiga jenis metode estimasi yang layak mengakomodir penelitian ini yaitu metode pooled least square, fixed effect, dan random effect. Serangkaian uji dilakukan untuk menentukan pemilihan metode terbaik dalam mengolah data dalam penelitian ini. Selanjutnya dilakukan uji-uji dari hasil estimasi untuk menjamin hasil estimasi koefisien bersifat Best Linear Unbiased Estimator (BLUE) dengan mengikuti asumsi Teorema Gauss-Markov.

\section{ANALISIS DAN PEMBAHASAN}

Berdasarkan seluruh rangkaian pengujian atas model di atas (persamaan 21), maka metode estimasi yang digunakan dalam penelitian ini adalah metode fixed ffect. Hasil pada Tabel 1 memperlihatkan bahwa nilai probabilitas $\mathrm{F}$ memiliki p-value yang cukup kecil sehingga dapat disimpulkan bahwa model secara keseluruhan mampu memengaruhi variabel tidak bebas dengan baik. Besaran $\mathrm{R}^{2}$ dalam hasil estimasi model mencapai 0,248 . Hal ini menunjukkan bahwa seluruh variabel bebas mampu menjelaskan total variasi dari variabel tidak bebas sebesar 24,8 persen.

Tabel 1

Hasil Estimasi Model Fixed Effect

Variabel Tidak Bebas: Pertumbuhan PDRB per Kapita Tanpa Migas

\begin{tabular}{lr}
\hline \multicolumn{1}{c}{ Variabel Bebas } & Koefisien \\
\hline Kondisi Inisial PDRB per Kapita $\left(\mathrm{LnPDRB}_{\mathrm{t}-1}\right)$ & $-0,0484$ \\
& $(-0,0375)$ \\
Perubahan Tingkat Modal Manusia $(\triangle \mathrm{APM})$ & $0,00206^{*}$ \\
& $(0,00117)$ \\
& 0,0986 \\
Rasio Pengeluaran Pemerintah (PP) & $(0,109)$ \\
& $0,326^{*}$ \\
Pembentukan Modal Tetap Bruto (PMTB $\mathrm{t}-1)$ & $(0,166)$ \\
Kontribusi Minyak dan Gas terhadap PDRB $(\mathrm{MG})$ & $0,169^{* *}$ \\
& $(0,0689)$
\end{tabular}


Konstanta

Statistik F

Observasi

R-squared

Catatan: Nilai Standard Error berada di dalam tanda kurung

${ }^{* * *} \mathrm{p}<0,01,{ }^{* *} \mathrm{p}<0,05,{ }^{*} \mathrm{p}<0,1$

Hasil estimasi yang disajikan pada Tabel 1 memperlihatkan beberapa variabel yang memiliki pengaruh signifikan, yang ditunjukkan oleh tanda bintang pada setiap koefisien variabel. Variabel-variabel tersebut dijelaskan sebagai berikut:

1. Kondisi Inisial PDRB Per Kapita

Kondisi inisial PDRB per kapita yang diwakili oleh variabel LnPDRB $_{\mathrm{t}-1}$ pada model menunjukkan arah hubungan negatif. Hal ini mengindikasikan bahwa semakin tinggi pendapatan, maka pertumbuhan ekonomi akan semakin lambat. Namun demikian, variabel ini secara statistik tidak memiliki pengaruh yang signifikan.

2. Perubahan Tingkat Modal Manusia

Kondisi tingkat modal manusia yaitu variabel $\triangle \mathrm{APM}$ pada model menunjukkan arah hubungan positif dan signifikan pada tingkat signifikansi 10 persen. Hal ini menunjukkan bahwa variabel angka partisipasi murni sebagai proksi dari modal manusia secara statistik signifikan memengaruhi pertumbuhan ekonomi dengan setiap perubahan angka partisipasi murni sebesar 1 persen poin, ceteris paribus, secara positif akan berpotensi meningkatkan pertumbuhan ekonomi sebesar 0,00206 persen.

3. Pengeluaran Pemerintah

Rasio pengeluaran pemerintah yang ditunjukkan oleh variabel PP pada model menunjukkan arah hubungan positif. Hal ini mengindikasikan semakin besar kontribusi pengeluaran pemerintah, maka akan berpotensi meningkatkan pertumbuhan ekonomi.
Namun variabel ini tidak signifikan memengaruhi variabel pertumbuhan ekonomi.

4. Pembentukan Modal Tetap Bruto (PMTB)

Indikator investasi melalui tingkat PMTB relatif terhadap PDRB diwakilkan oleh variabel PMTB lag satu pada model menunjukkan arah hubungan positif dan signifikan pada tingkat signifikansi 10 persen. Hal ini membuktikan bahwa semakin besar kontribusi pembentukan modal tetap bruto terhadap PDRB pada tahun ini, maka akan meningkatkan pertumbuhan ekonomi di tahun depan. Hasil estimasi model menjelaskan bahwa setiap peningkatan 1 persen kontribusi PMTB di dalam PDRB, ceteris paribus, maka akan meningkatkan pertumbuhan ekonomi di tahun depan sebesar 0,326 persen.

5. Kontribusi Minyak dan Gas terhadap PDRB

Kontribusi Minyak dan Gas terhadap PDRB yang diwakilkan oleh variabel MG menunjukkan arah hubungan positif dan signifikan pada tingkat signifikansi 5 persen. Hal ini membuktikan bahwa semakin besar kontribusi migas di dalam PDRB, maka pertumbuhan ekonomi secara relatif akan lebih tinggi. Hasil estimasi model menjelaskan bahwa setiap peningkatan 1 persen kontribusi migas di dalam PDRB, ceteris paribus, maka pertumbuhan ekonomi tumbuh lebih cepat sebesar 0,169 persen.

Berdasarkan hasil pengolahan data menggunakan pendekatan ekonometrika, ditemu- 
kan bahwa provinsi yang memiliki ketergantungan terhadap minyak dan gas justru mengalami pertumbuhan PDRB per kapita tanpa migas yang relatif lebih cepat. Hasil tersebut memperlihatkan bahwa menolak hipotesis nol sehingga hasil tersebut menjadi bukti bahwa untuk kasus Indonesia, tidak terjadi fenomena resource curse khususnya untuk model dutch disease yang menyatakan bahwa daerah yang memiliki ketergantungan terhadap sumber daya alam akan mengalami penurunan daya saing di sektor lain dalam perekonomian. Berdasarkan hasil pengolahan data, ditemukan bahwa provinsi yang memiliki ketergantungan terhadap minyak dan gas justru mengalami pertumbuhan PDRB per kapita tanpa migas yang lebih cepat. Hal tersebut juga dikonfirmasi oleh arah pengaruh positif antara variabel MG terhadap pertumbuhan PDRB per kapita tanpa migas. Hal tersebut menunjukkan bahwa kegiatan ekstraksi migas mampu mendorong percepatan pertumbuhan sektor-sektor lain di luar sektor migas.

Pertumbuhan yang lebih cepat di sektorsektor lain pada provinsi-provinsi yang kaya akan minyak dan gas merupakan hal yang sangat positif mengingat keberadaan minyak dan gas yang akan semakin langka kedepannya sehingga perekonomian dapat terus tumbuh dan berpindah ke sektorsektor lainnya. Keberhasilan pengelolaan sumber daya alam khususnya minyak dan gas menjadi kunci penting dalam keberhasilan pembangunan jangka panjang. Pendapatan dari komoditas minyak dan gas tidak dapat dijadikan tumpuan bagi pemerintah daerah secara terus-menerus. Hal tersebut dikarenakan adanya tren penurunan produksi minyak dan gas. Untuk itu perlu dilakukan pemanfaatan dana hasil pendapatan minyak dan gas. Beberapa hal yang penting dilakukan bagi pemerintah adalah meningkatkan investasi publik dari dana pendapatan migas.

\section{Gambar 6}

Hubungan Kontribusi Minyak dan Gas dengan Pertumbuhan PDRB

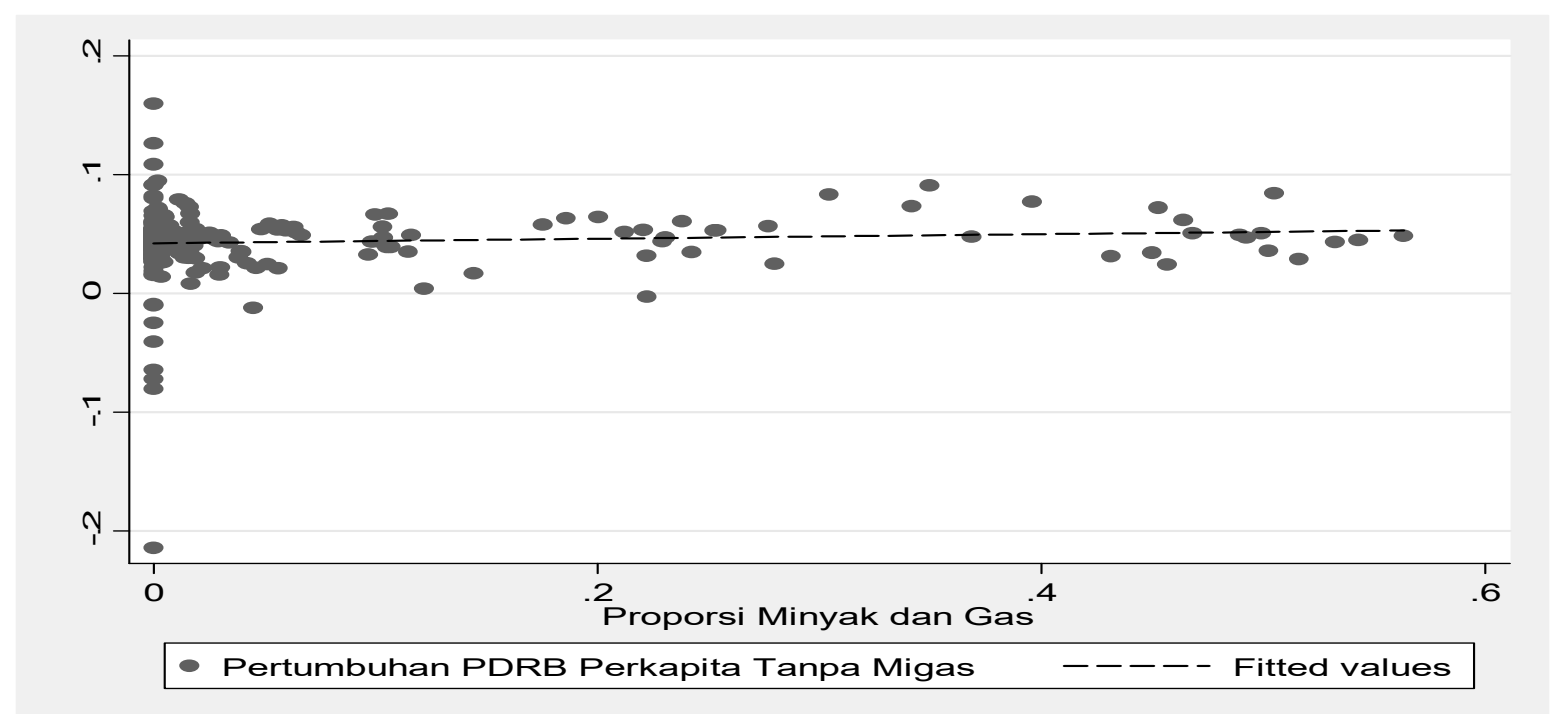

Sumber: Hasil olahan penulis

Hal pertama yang penting untuk diperhatikan adalah sistem institusi yang baik dan transparan sehingga dapat mengelola sumber daya alam dengan baik.
Costa dan Santos (2013) menyatakan bahwa penguatan fungsi intitusi yang baik merupakan salah satu cara menghindar dari kutukan sumber daya alam. Melalui institusi 
yang baik, hasil dari kegiatan ekstraksi sumber daya alam dapat dialokasikan dengan efisien serta meningkatkan transparansi sehingga menghilangkan kegiatankegiatan perburuan rente.

Minyak dan gas merupakan sumber daya alam yang tidak dapat diperbaharui, sehingga pendapatan dari SDA migas tersebut juga perlu dialokasikan dengan hati-hati dan efisien agar dapat bermanfaat bagi masyarakat seluas-luasnya. Salah satunya dengan melakukan investasi atas pendapatan tersebut. Investasi yang dapat dilakukan antara lain meningkatkan kualitas pendidikan masyarakat mengingat pendidikan merupakan sumber peningkatan kualitas faktor produksi manusia (tenaga kerja). Dengan begitu, masyarakat dapat berinovasi dan menjadi lebih produktif sehingga dapat berpindah ke sektor-sektor lain dan tidak harus bergantung pada pendapatan dari sektor pertambangan minyak dan gas. Kebijakan atas pengelolaan dana pendapatan hasil migas ini telah tertuang di dalam aturan dana bagi hasil minyak dan gas, yang tercantum dalam UndangUndang No 33 Tahun 2004 dan Peraturan Pemerintah No 55 Tahun 2005, sehingga dari seluruh persentase pembagian untuk daerah, sekitar 0,5 persen di antaranya wajib digunakan untuk bidang pendidikan. Namun demikian, selain kebijakan tersebut, pemerintah daerah dapat melakukan investasi pendidikan yang lebih besar agar manfaat dari dana bagi hasil tersebut juga lebih besar.

Selain investasi pendidikan, investasi lainnya adalah pembangunan infrastruktur. Pembangunan infrastruktur dapat dipercepat menggunakan dana bagi hasil yang didapatkan oleh daerah. Pemilihan infrastruktur yang strategis dalam menyokong pembangunan sektor-sektor lain menjadi kunci dalam pemanfaatan dana bagi hasil migas. Dengan mendorong pertumbuhan sektor-sektor lain melalui pembangunan infrastruktur, maka pemerintah daerah dapat secara perlahan mengganti sumber pendapatan pemerintah dari yang berbasis pendapatan komoditas menjadi pendapatan berbasis pajak.

Pemanfaatan dana hasil minyak dan gas juga harus bersifat jangka panjang. Hal ini bisa dilakukan melalui kebijakan dana sumber daya alam. Sebagaimana negara Norwegia sebagai salah satu acuan negara yang mampu memanfaatkan pendapatan sumber daya alamnya dengan baik sehingga dapat menjadikan sumber daya alam sebagai salah satu sumber untuk menyejahterakan masyarakat. Keberhasilan Negara Norwegia dalam mengelola keberadaan sumber daya alamnya dengan baik sehingga mensejahterakan masyarakat tersebut didukung oleh penelitian Holden (2013) dan Mideksa (2013). Aturan mengenai pemanfaatan dana sumber daya alam yang ketat dibuat untuk menjaga penggunaan dana tersebut agar memiliki pengaruh positif yang berkelanjutan. Aturan tersebut dapat berupa batasanbatasan mengenai penggunaan dana minyak dan gas yang hanya boleh untuk kegiatan investasi sehingga dana tersebut tidak akan habis.

\section{SIMPULAN DAN SARAN}

Berdasarkan hasil analisis yang telah dilakukan dapat ditemukan bahwa provinsiprovinsi yang memiliki ketergantungan terhadap komoditas minyak dan gas, tercermin dari kontribusi minyak dan gas terhadap PDRB, mengalami pertumbuhan PDRB per kapita tanpa migas yang relatif lebih cepat dibandingkan dengan provinsi yang tidak memiliki minyak dan gas. Pernyataan ini didukung oleh hasil estimasi model yang menunjukkan adanya pengaruh positif dari variabel kontribusi minyak dan gas dalam PDRB terhadap variabel pertumbuhan PDRB per kapita tanpa migas. Hasil tersebut menunjukkan bahwa provinsi-provinsi yang memiliki kekayaan minyak dan gas menikmati pertumbuhan yang relatif lebih tinggi di sektor-sektor selain minyak dan gas dibandingkan provinsi-provinsi yang memiliki lebih sedikit proporsi minyak dan gas dalam PDRBnya. Beberapa variabel lainnya yang juga ber- 
pengaruh positif secara signifikan ter- hadap pertumbuhan PDRB per kapita tanpa migas antara lain adalah pertumbuhan kapital yang diwakili oleh rasio pembentukan modal tetap bruto terhadap PDRB di mana semakin tinggi pertumbuhan kapital maka akan mendorong pertumbuhan PDRB per kapita untuk semakin lebih tinggi. Hal tersebut mengingat bahwa penambahan modal akan memberikan penambahan faktor produksi sehingga output akan semakin tinggi.

Perubahan tingkat modal manusia yang diwakili oleh perubahan angka partisipasi murni tingkat SMA juga memiliki pengaruh positif secara signifikan. Modal manusia yang diwakili oleh indikator angka partisipasi murni menunjukkan peran pendidikan pada pertumbuhan ekonomi. Dengan memiliki pendidikan yang lebih baik, manusia atau tenaga kerja sebagai faktor produksi memiliki kemampuan untuk berproduksi semakin efektif dan efisien.

Berdasarkan hasil temuan di atas, dapat disimpulkan bahwa untuk kasus Indonesia, tidak ditemukan adanya fenomena resource curse antara sumber daya alam migas dan sektor-sektor lain di luar minyak dan gas. Penelitian ini membuktikan bahwa sumber daya alam minyak dan gas telah menjadi anugerah bagi provinsi yang memilikinya karena telah berhasil mendorong sektorsektor di luar minyak dan gas untuk tumbuh lebih cepat dibandingkan provinsi-provinsi lain. Penelitian ini memiliki beberapa keterbatasan antara lain adalah indikator kekayaan alam yang digunakan adalah minyak dan gas serta hanya dilihat dari kontribusi terhadap PDRB. Untuk penelitian selanjutnya, dapat digunakan beberapa jenis indikator lain yang lebih spesifik seperti dana bagi hasil, nilai ekspor komoditas dan pengukuran lainnya. Selain itu, penelitian ini hanya mencakup analisis di tingkat provinsi sehingga untuk penelitian ke depan dapat menggunakan data yang dapat digunakan untuk menganalisis pada tingkat kabupaten atau kota agar penelitian tersebut menjadi lebih dalam dan memperkaya hasil temuan studi-studi yang sudah ada selama ini. Selanjutnya variabel kontrol yang mungkin terlewatkan dalam penelitian ini dapat dipertimbangkan untuk ditambahkan untuk memastikan hasil estimasi dan analisis menjadi lebih tepat. Selain itu, penambahan data juga dapat dilakukan agar analisis yang akan dilakukan nantinya dapat melihat dalam jangka waktu yang lebih panjang.

\section{DAFTAR PUSTAKA}

Atkinson, G. dan K. Hamilton. 2003. Savings, Growth and the Resource Curse Hypothesis. World Development 31(11): 17931807.

Auty, R. M. 1994. Industrial Policy Reform in Six Large Newly Industrializing Countries: The Resource Curse Thesis. World Development 22(1): 11-26.

Badan Pusat Statistik. 2016. Statistik Indonesia 2016. Jakarta, Indonesia. www.bps.go.id.

Barro, R. 2003. Determinants of Economic Growth in a Panel of Countries. Annals of Economics and Finance 4(2): 231-274.

Bjorvatn, K., M. R. Farzanegan, dan F. Schneider. 2012. Resource Curse and Power Balance: Evidence from Oil-Rich Countries. World Development 40(7): 1308-1316.

Boschini, A. D., J. Pettersson, dan J. Roine. 2007. Resource Curse or Not: A Question of Appropriability. Scandinavian Journal of Economics 109: 593-617.

Brunnschweiler, C. N. dan E. H. Bulte. 2009. Natural Resources and Violent Conflict: Resource Abundance, Dependence, and the Onset of Civil Wars. Oxford Economic Papers 61(4): 651-674.

Cavalcanti, T. V. D. V., K. Mohaddes, dan M. Raissi. 2011. Growth, Development and Natural Resources: New Evidence Using A Heterogeneous Panel Analysis. The Quarterly Review of Economics and Finance 51(4): 305-318.

Collier, P. dan A. Hoeffler. 1998. On Economic Causes of Civil War. Oxford Economic Papers 50(4): 563-573.

Costa, H. K. M. dan E. M. Santos. 2013. Institutional Analysis and the "Resource 
Curse" in Developing Countries. Energy Policy 63: 788-795.

Davis, G. 2011. The Resource Drag. Institute for European Environmental Policy 8: 156176.

Ebrahimzadeh, C. 2012. Dutch Disease: Wealth Managed Unwisely. International Monetary Fund. http://www.imf. org/external/pubs/ft/fandd/basics/dutch.htm Diakses tanggal 16 Juli 2016.

Fan, R., Y. Fang, dan S. Y. Park. 2012. Resource Abundance and Economic Growth in China. China Economic Review 23(3): 704-719.

Gylfason, T. 2001. Natural Resource, Education, and Economic Development. European Economic Review 45(4-6): 847859.

Holden, S. 2013. Avoiding the Resource Curse the Case Norway. Energy Policy 63: 870-876.

Hodler, R. 2006. The Curse of Natural Resources in Fractionalized Countries. European Economic Review 50(6): 13671386.

Humphreys, M., J. D. Sachs, dan J. E. Stiglitz. 2007. Escaping the Resource Curse. Columbia University Press. New York.

James, A. G. dan R. G. James. 2011. Do Resource Dependent Regions Grow Slower Than They Should?. Economics Letters 111(3): 194-196.

James, A. 2015. The Resource Curse: a Statistical Mirage. Journal of Development Economics 114: 55-63.

Komarulzaman, A. dan A. S. Alisjahbana. 2006. Testing the Natural Resource Curse Hypothesis in Indonesia: Evidence at the Regional Level. Working Paper in Economics and Development Studies No 200602. Department of Economics, Padjajaran University.

Kementerian Energi dan Sumber Daya Mineral. 2016. Handbook of Energy and
Economic Statistics of Indonesia 2016. http://www.esdm.go.id/.

Mankiw, N. G. 2012. Principles of Economics. South Western Cengage Learning. USA.

Mehlum, H., K. Moene, dan R. Torvik. 2006. Institutions and the Resource Curse. The Economic Journal 116(508): 1-20.

Mideksa, T. K. 2013. The Economic Impact of Natural Resources. Journal of Environmental Economics and Management 65(2): 277-289.

Murshed, S. M. dan L. A. Serino. 2011. The Pattern of Specialization and Economic Growth: The Resource Curse Hypothesis Revisited. Structural Change and Economic Dynamics 22(2): 151-161.

Papyrakis, E. dan R. Gerlagh. 2007. Resource Abundance and Economic Growth in The United States. European Economic Review 51(4): 1011-1039.

Pick, D. dan H. H. Thein. 2010. Development Failure and the Resource Curse: the Case of Myanmar. International Journal of Sociology and Social Policy 30(5/6): 267-279.

Ross, M. L. 2015. What Have We Learned about the Resource Curse. Annual Review of Political Science 18(1): 239-259.

Rosser, A. 2004. Why did Indonesia Overcome the Resource Curse?. Institute of Development Studies Working Paper 222.

Sachs, J. D. dan A. M Warner. 1995. Natural Resource Abundance and Economic Growth. NBER Working Paper 5398. National Bureau of Economic Research.

Sachs, J. D. dan A. M. Warner. 2001. The Curse of Natural Resource. European Economic Review 45(4-6): 827-838.

Torvik, R. 2002. Natural Resources, Rent Seeking and Welfare. Journal of Development Economics 67(2): 455-470. 